American Journal of Applied Sciences 3 (11): 2134-2135, 2006

ISSN 1546-9239

(C) 2006 Science Publications

\title{
Characteristic Curve of a Fuel Cell
}

\author{
Muzamir Isa, Baharuddin Ismail, Che Mat Hadzer, Ismail Daut and Faizah Abu Bakar \\ School of Electrical System Engineering, KUKUM, Malaysia
}

\begin{abstract}
The aim of this study was to deliver information about the features of fuel cells. It cover analysis of theory and experiment done using a set of tool called Hydro Genius Teach. The experiment is about investigating the characteristic curve of a fuel cell from the processes of renewable energy. Others objectives of this study were to analyze current usage of renewable energy in the world and to do analysis on features of fuel cell as one of ways in renewable energy.
\end{abstract}

Key words: Fuel cell, hydrogen fuel cell and renewable energy

\section{INTRODUCTION}

A hydrogen fuel cell produces an emf by combining hydrogen and oxygen chemically. A conventional battery supplies electrical energy in the same way except that the reactants are eventually used up and the battery has to be disposed of recharged ${ }^{[1]}$.

A fuel cell will provide energy so long as hydrogen and oxygen are supplied to $\mathrm{it}^{[2]}$. The current and voltage output will depend upon the load applied to the fuel cell and can be seen from its characteristic curve. As the processes in a fuel cell are the reverse of electrolysis it is useful to compare the characteristic curves of the fuel cell and electrolyser.

\section{MATERIALS AND METHODS}

In order to use the fuel cell as a power source, it must be provided with a supply of hydrogen and oxygen from the electrolyser. Set up the apparatus as shown in Fig. 1 and 2.

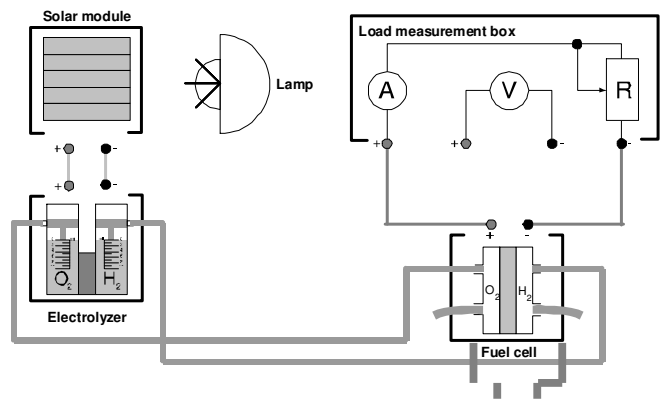

Fig. 1: Schematic connection for determining characteristic curve of a fuel cell

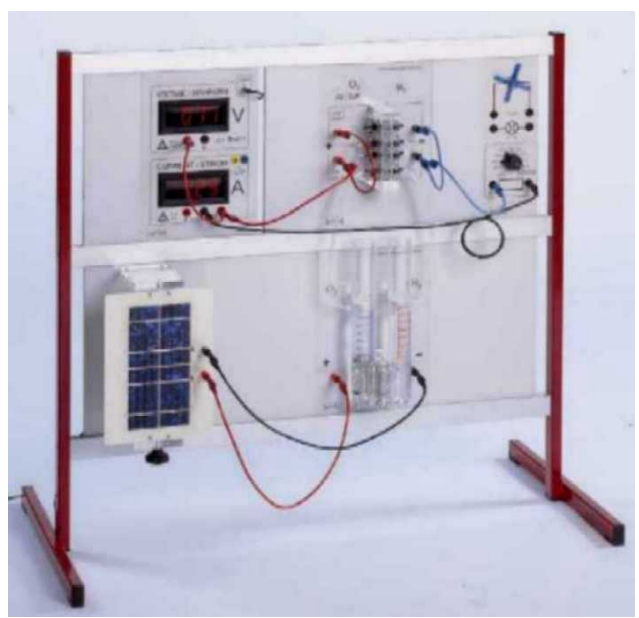

Fig. 2: Experimental test set for hydro genius teach equipment

The gas tubes between the electolyser and the fuel cell are correctly connected and both of the gas storage cylinders of the electrolyser are filled with distilled water up to the $0 \mathrm{~mL}$ mark. By u sing the illuminated solar module, a constant current to the electrolyser is set of between $200 \mathrm{~mA}$ and $300 \mathrm{~mA}$.

The solar module position must be towards the light source in such a way that gas production can be clearly observed. Purge the complete system (consisting of the electrolyser, fuel cell and tubes) for 5 min with the gases produced and the rotary switch on the load on the load measurement box is set to $3 \Omega$ for $3 \mathrm{~min}$. Purge the system again with the rotary switch in the 'OPEN' position for $3 \mathrm{~min}$.

The characteristic curve of the fuel cell was recorded by varying the measurement resistance.

\section{RESULTS AND DISCUSSION}

Figure 3 shows the characteristic of current and voltage behavior in fuel cell using $250 \mathrm{~mA}$ electrolyser current. The voltage decreased when the current increased. Fuel cell voltage efficiency using $250 \mathrm{~mA}$ electrolyser current can be calculated as follows: 
$\eta=($ Actual voltage $/$ Theoretical voltage $) * 100 \%$

$=\left(\mathrm{E}_{\mathrm{K}} / \mathrm{E}_{\mathrm{O}}\right) * 100 \%$

$=(0.96 / 1.23) * 100 \%$

$=78.05 \%$

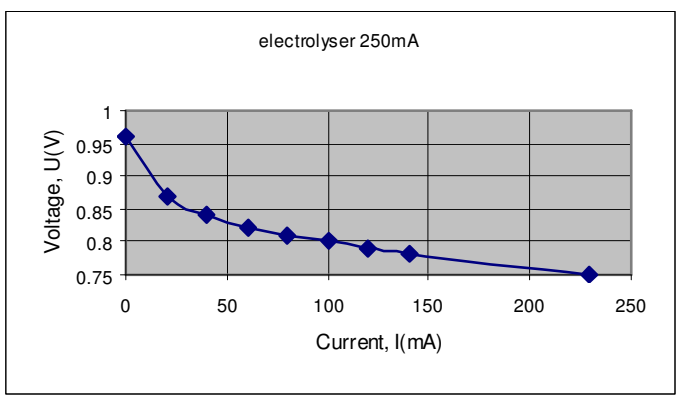

Fig. 3: Characteristic curve of the fuel cell

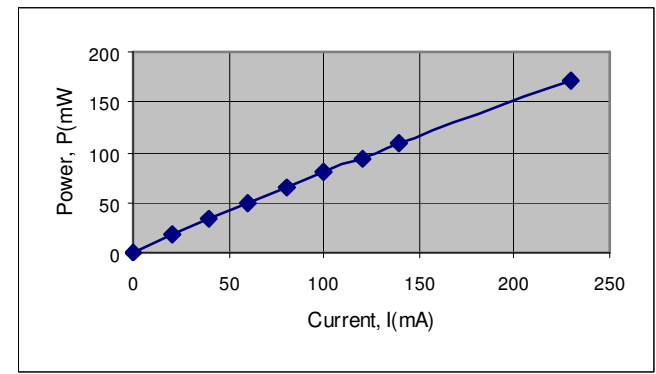

Fig. 4: Power curve of the fuel cell

The processes in the fuel cell are the reverse of those that take place in electrolysis. In the electrolysis of water, at least $1.23 \mathrm{~V}$ must be applied before the water begins to split, as a rule the voltage is higher.

In the case of a fuel cell (a galvanic cell), less voltage is generated for the same reasons. Here too, the characteristic curve is affected by the materials used for the electrodes (catalysis), the internal resistance, the temperature and the volume of hydrogen and oxygen being supplied.

At very small or zero current drain, the voltage across the fuel cell amounts to approximate $0.9 \mathrm{~V}$. This voltage is called open circuit voltage. In the case of the fuel cell, it is very dependent on the volume and purity of the input gases. The more current is drawn from the fuel cell, the smaller the voltages becomes. Accordingly, the is an exponential increase in the current as the voltage declines.
Figure 4 represents a P-I diagram for the operating point of the electric motor. It can be seen that the motor does not run at the optimal point, in example hydrogen is being lost.

In practice, efforts are made to drawn as much as possible from the fuel cell. However, the efficiency of the fuel cell declines at high current values, so that the task here is to find an optimum operating point.

\section{CONCLUSION}

This study has illustrated the potential of a hydrogen and fuel cell storage system for electricity. With this analysis we see that a system like this not only work effectively but also to provide a more environmental friendly solution for the future. The difference between the battery and the fuel cell system lie in the environmental concerns of the two systems. We concluded that the fuel cell system is a more environmental system than the battery because the materials that are used together with the high reliability and effective operation give a greater lifetime than the battery system.

In the past, the limiting factors of renewable energy have been the storage and transport of that energy. With the use of fuel cells and hydrogen technology, electrical power from renewable energy sources can be delivered where and when required, cleanly, efficiently and in a sustainable manner.

\section{REFERENCES}

1. Tambe, R and Hampton, 2003. Renewable Energy. Key Note Ltd.

2. Linden, D. and T.B. Reddy, 2002. Handbook of Batteries. New York: Mc Graw-Hill. 